\title{
Erratum to: An integrated multimethodological approach for characterizing the materials and pigments on a sarcophagus in St. Mark, Marcellian and Damasus catacombs
}

\author{
Roberta Iannaccone $^{1} \cdot$ Susanna Bracci $^{1} \cdot$ Emma Cantisani $^{1} \cdot$ Barbara Mazzei $^{2}$
}

Published online: 18 December 2015

(C) Springer-Verlag Berlin Heidelberg 2015

Erratum to: Appl. Phys. A (2015) 121:1235-1242

DOI 10.1007/s00339-015-9495-3

The original version of this article unfortunately contained a mistake.

The first and last names of the authors were interchanged. The correct names are Roberta Iannaccone, Susanna Bracci, Emma Cantisani, Barbara Mazzei.

The online version of the original article can be found under doi:10.1007/s00339-015-9495-3.

Roberta Iannaccone

iannaccone@icvbc.cnr.it

1 ICVBC-CNR Institute for Conservation and Valorization of Cultural Heritage, National Research Council, Via Madonna del Piano 10, 50019 Sesto Fiorentino, Florence, Italy

2 Pontificia Commissione di Archeologia Sacra, Via Napoleone III 1, 00185 Rome, Italy 